\title{
Analisis Tingkat Religiusitas pada Mahasiswa yang Mengikuti Organisasi
}

\author{
Dony Darma Sagita ${ }^{1}$, Dede Miftah Fauzi ${ }^{2}$, Jumadi Mori Salam Tuasikal ${ }^{3}$ \\ 1,2 Prodi Bimbingan dan Konseling Universitas Muhammadiyah Prof. DR. HAMKA \\ ${ }^{3}$ Jurusan Bimbingan dan Konseling Universitas Negeri Gorontalo \\ Email: Donyds@uhamka.ac.id
}

\begin{abstract}
ABSTRAK
Penelitian ini bertujuan untuk mendeskripsikan tingkat religiusitas pada mahasiswa yang mengikuti organisasi. Penelitian ini menggunakan metode penelitian deskriptif kuantitatif. Penarikan sampel dalam penelitian ini menggunakan Probability Sampling, dengan teknik Cluster Sampling. Hasil penelitian ini menunjukkan tingkat religiusitas mahasiswa yang mengikuti organisasi ini berada pada kategori sangat tinggi dengan persentase 28\%, dan kategori tinggi sebesar $66 \%$. Hal ini menunjukkan bahwa sebagian besar subjek penelitian memiliki tingkat religiusitas yang tergolong tinggi. Maka dari itu perlu adanya upaya mahasiswa yang mengikuti organisasi untuk mempertahankan religiusitas.
\end{abstract}

Kata kunci : Religiusitas; Mahasiswa yang mengikuti organisasi

\section{ABSTRACT}

The study aims to describe the religious level of students whofollow the organization. The study uses a quantitative descriptive study method. The withdrawal of samples in this research uses sampling, by cluster sampling techniques. The findings suggest that the religiosity of the student who attends the organization falls at a high rating of $28 \%$, and a high category of $66 \%$. This suggests that most research subjects have high religious levels. Therefore, effort is required for students who join the organization to maintain religiosity.

Keywords: Religiosity, Students who follow organizations

(C) 2021 Dony Darma Sagita, Dede Miftah Fauzi, Jumadi Mori Salam Tuasikal Under the licence CC BY-SA 4.0

\section{PENDAHULUAN}

Mahasiswa ialah peserta didik yang terdaftar dan menjalani pendidikan di perguruan tinggi baik dari akademik, politeknik, sekolah tinggi, institut, dan universitas yang berusia 18 sampai 25 tahun (Hartaji dalam Hulukati \& Djibran, 2018). Seorang mahasiswa yang berusia 18 sampai 25 tahun ini, dikategorikan dan tergolong pada masa remaja akhir sampai 
masa dewasa awal, pada tahap perkembangan ini, mahasiswa memiliki tugas perkembangan untuk pemantapan pendirian hidup (Yusuf dalam Hulukati et al., 2018). Pada usia ini, selain berstatus sebagai orang dewasa, mahasiswa juga memiliki banyak peran baru yang siap dihadapi (Muchtar, 2019).

Dalam perkembangan mahasiswa, ada tahapan-tahapan yang didalamnya terdapat tugas perkembangan. Perlu adanya pemenuhan tugas perkembangan, agar tahap perkembangan selanjutnya tidak terjadi keterhambatan. Beberapa perubahan pada aspek fungsional yang dialami individu, yang terdiri dari fisik, psikologis, serta sosial menjadi penyebab munculnya tuntutan dan tugas perkembangan pada mahasiswa (Hulukati et al., 2018). Seperti halnya siswa SD yang memasuki SMP, atau siswa SMP yang memasuki SMA, mahasiswa baru juga memulai jenjang baru ketika memasuki perguruan tinggi, setiap jenjang pendidikan mempunyai karakteristik permasalahan. Bagi mahasiswa baru, sesuatu hal baru bisa menjadi hal yang menarik untuk dijalani, ataupun sebaliknya, kondisi atau situasi yang baru, menjadi kekhawatiran bagi beberapa mahasiswa baru (Iflah \& Listyasari, 2013).

$$
\text { Penyesuaian diri terhadap }
$$
lingkungan baru, menjadi suatu permasalahan bagi mahasiswa baru. Hal ini menimbulkan dampak bagi diri mahasiswa, mahasiswa merasa pesimis terhadap kemampuan diri sendiri dalam memimpin organisasi, menurunnya kesehatan, dan lain-lain menjadi dampak buruk yang didapatkan mahasiswa (Rosiana, 2011). Tuntutan bagi mahasiswa bukan hanya sekadar prestasi akademik, melainkan kemampuan softskill yang dimiliki perlu untuk dikembangkan (Sharma dalam Oetomo, Yuwanto, \& Rahaju, 2019).

Hal umum yang sering dialami oleh remaja adalah krisis identitas diri yang disebabkan oleh berbagai faktor. Misalnya adanya kurang kesesuaian antara hal yang diinginkan dengan kenyataan. Hal tersebut memberikan dampak dan merugikan remaja, misalnya wajah kurang enak dipandang, teman terbatas, sikap tertutup, prestasi belajar menurun, badan terlalu gemuk atau kurus, dan kurang berani menghadapi tantangan. Ada pula yang lebih memprihatinkan yaitu tindakantindakan destruktif yang cenderung dilakukan, rentannya kenakalan remaja. Salah satunya disebabkan karena remaja kurang religius, biasanya seorang remaja minim dalam pendidikan agama sehingga masih sangat lemah dalam mengenal dan memahami tentang Tuhan. Kurangnya pendalaman ajaran agama, menjadikan 
sangat rendahnya etika moral remaja, hal itu menjadikan tidak adanya kontrol diri pada remaja (Huriati \& Hidayah, 2016).

Religius berorientasi dan berkaitan dengan kepribadian seperti kecemasan, kontrol diri, keyakinan irasional, depresi dan sifat kepribadian lain (Bergin dalam Kurniawan \& Dwiyanti, 2013). Ada istilah kesadaran agama (religious consciousness) yang dikenal dalam psikologi agama, yaitu aspek mental yang dirasakan dari segi aktivitas agama (Daradjat dalam Listiari, 2011).

Krisis identitas seperti di atas, menjadi kekhawatiran mahasiswa tidak diakui keberadaannya, juga tidak dihargai oleh orang lain atau selalu mendapat ejekan dari orang lain sehingga mahasiswa mencoba bergabung dengan suatu perkumpulan atau organisasi yang mereka minati (Chamadi \& Sumantri, 2019). Terutama ide dari suatu organisasi berguna bagi mahasiswa sebagai media untuk lebih bisa mengeksplor diri dan berkembang, serta bentuk aktualisasi diri. Terlebih organisasi yang memiliki label keislaman, hal ini untuk meningkatkan kompetensi religiusitas pada diri mahasiswa. Mahasiswa memiliki karakteristik pribadi dan minat sesuai dengan yang dilakukan oleh organisasi bernuansa Islam, hal itu tergambar dalam tujuan gerakan mahasiswa Islam saat ini (Hadziq, 2019).
Banyak sekali organisasi mahasiswa Islam yang bisa diikuti oleh mahasiswa, diantaranya yaitu HMI, IMM, PMII, KAMMI dan beberapa organisasi mahasiswa lain merupakan wadah untuk mengaktualisasikan diri. Berbagai Perguruan Tinggi memiliki ragam mahasiswa beragama, satuan terbesar dari mahasiswa adalah mahasiswa Islam. Gerakan mahasiswa Islam dijadikan sebagai orientasi bagi para mahasiswa, sehingga mahasiswa sangat bersemangat dalam berorganisasi (Chamadi et al., 2019).

Ikatan Mahasiswa Muhammadiyah (IMM) merupakan salah satu organisasi pergerakan mahasiswa Islam di Indonesia dan juga sekaligus sebagai Organisasi Otonom (Ortom) Muhammadiyah yang bergerak dibidang keagamaan, kemahasiswaan, dan kemasyarakatan (Nur \& Ramli, 2017). Sebagaimana dipertegas dalam AD IMM tercantum pada BAB I Pasal 1 dan 2 yang berbunyi bahwa "Ikatan Mahasiswa Muhammadiyah (IMM) memiliki arti suatu gerakan Mahasiswa Islam yang berakidah Islam bersumber Al Quran dan As Sunnah" (Sofa, 2015). Kemudian IMM sendiri didirikan di Surakarta tanggal 29 Syawal $1384 \mathrm{H}$ bertepatan dengan tanggal 14 Maret 1964 M. Didirikannya IMM tentu memiliki tujuan, dan tujuannya yaitu 
"Mengusahakan terbentuknya akademisi Islam yang berakhlak mulia dalam rangka mencapai tujuan Muhammadiyah" (Lestari, 2017). Untuk mencapai tujuan tersebut, IMM mempunyai identitas gerakan yang terdiri dari Enam Penegasan, Identitas IMM, Trilogi Ikatan, Tri Kompetensi Dasar (TKD), Nilai Dasar Ikatan, dan Profil Kader Ikatan sebagai bekal dalam setiap perkaderan dan pergerakan (Sutanti et al., 2011).

Tri Kompetensi Dasar (TKD) salah satu dari Enam Penegasan tersebut memiliki tiga kompetensi yaitu terdiri dari religiusitas, intelektualitas, dan humanitas yang ditanamkan sejak awal dalam perkaderan IMM yaitu Darul Arqam Dasar. Dalam proses perkaderan, Tri Kompetensi Dasar ini menjadi komponen utama atau pokok yang bersifat wajib (Sutanti et al., 2011). Tiga kompetensi ini menjadi identitas kader IMM, IMM sebagai organisasi perkaderan yang memiliki nilai-nilai religiusitas, IMM memberikan sumbangsih dalam pembaharuan keagamaan baik dari segi pemahaman pemikiran maupun realisasinya (Nur et al., 2017). Begitupun dengan intelektualisme menjadi kunci utama keberadaan IMM, maka dari itu harus dibuktikan oleh kader-kadernya (Amirullah dalam Sholeh, 2017). Selanjutnya ciri khas IMM adalah organisasi berbasis humanitas. Hal yang menjadi komitmen kader dalam menjunjung cita-cita besar organisasi yaitu untuk membangun dan mewujudkan dunia yang lebih humanis-transenden yaitu dengan gerakan kemanusiaan demi terwujudnya rahmat bagi sekalian alam (Amirullah, 2016). Tri Kompetensi Dasar sebagai suatu hal yang menjadi tuntutan kader Ikatan Mahasiswa Muhammadiyah (IMM) yang merupakan salah satu bentuk penekanan terhadap perlunya integrasi ilmu, agama, dan kemanusiaan (Sholeh, 2017)

Konsep dalam penelitian ini, lebih terfokuskan pada salah satu Tri Kompetensi Dasar yaitu religiusitas, sebagaimana permasalahan yang telah diamati oleh peneliti. Religiusitas yang menjadi salah satu dari Tri Kompetensi Dasar sering kali menjadi sorotan. Menuai kritik dari berbagai pihak, banyak anggapan bahwa IMM tidak religius. Anggapan IMM tidak religius yang dimaksud adalah sebagian orang menafsirkan tentang religiusitas lebih mengarah pada kompetensi menjalankan ritual keagamaan seperti salat, membaca dan menghafal quran, adzan, hadir di pengajian keislaman, dan lain sebagainya. Terkadang fenomena di lapangan mendukung hal tersebut, ada beberapa pengurus atau kader IMM yang kurang 
aktif dalam kegiatan seperti di atas. Sehingga orang-orang semakin beranggapan kuat bahwa kader IMM tidak religius. Hal itu bertolak belakang dengan religiusitas yang menjadi bagian dari Tri Kompetensi Dasar secara ideal harus dimiliki kuat oleh kader IMM.

Ketaatan dan komitmen seseorang terhadap agamanya, merupakan hal yang disorot dalam keberagamaan seseorang, dan pada dasarnya seseorang lebih menunjukkan ketaatan dan komitmennya terhadap agama dilihat pada proses-proses internalisasi nilai-nilai agama yang menyatu dalam diri individu sehingga terbentuk perilaku dalam keseharian (Glock dan Stark dalam Alwi, 2014). Religiusitas merupakan sebuah doktrin yang disampaikan oleh setiap agama terhadap pemeluknya yang berkaitan dengan masalah perilaku (Fetzer dalam Raudatussalamah \& Susanti, 2017). Religiusitas merupakan tingkah laku manusia sesuai ketentuan agama yang terdorong oleh suatu keadaan dalam diri individu (Jalaluddin dalam Sasmitho, 2013).

Pendapat di atas lebih menekankan pada ketaatan terhadap ajaran agamanya, yang diwujudkan dalam tingkah laku. Religiusitas adalah sebuah keyakinan, pengetahuan, dan pengalaman seseorang mengenai agama yang dianutnya, serta ketaatan seseorang dalam menjalankan ibadah ritual sebagai tanda menghayatinya terhadap agama yang dipeluknya dan menjadi perilaku yang diterapkan dalam kehidupan (Marliani, 2013).

Terdapat lima dimensi religiusitas yang merupakan bentuk komitmen dan tekad seseorang yang berkaitan dengan hidup dalam beragama. Berikut lima dimensi religiusitas tersebut yaitu: (1) ideological dimensio (religious belief,) keyakinan seseorang terkait dengan kebenaran agamanya. (2) ritualistic dimension (religious practice), tingkatan sejauh mana seseorang menunaikan kewajiban-kewajiban ritual agamanya. (3) experiential dimension (religious feeling), perasaan keagamaan yang pernah dialami dan dirasakan setiap orang. (4) intellectual dimension (religious knowledge), seberapa jauh seseorang mengetahui dan memahami ajaran-ajaran agamanya terutama yang ada dalam kitab suci, hadits, pengetahuan fiqih dan seterusnya. (5) consequential dimension (religious effects), sejauh mana dampak ajaran agama memengaruhi perilaku seseorang dalam kehidupan sosial (Glock dan Stark dalam Koenig, 2018; Darokah \& Safaria, 2005).

Religiusitas erat kaitannya dengan agama. Religiusitas dan agama merupakan satu kesatuan yang tidak dapat dipisahkan (Mangunwidjaya dalam Nuandri \& 
Widayat, 2014). Agama mengatur tata cara manusia dalam proses beribadah atau menyembah kepada Tuhan, sedangkan religiusitas menunjukkan sejauh mana kualitas manusia dalam beragama. Manusia beragama, akan terlihat kualitas dirinya dalam religiusitas (Putri, 2012).

Dari berbagai fenomena yang terjadi di lapangan, dan berdasarkan argumentasi teoritik di atas, menarik perhatian peneliti untuk melakukan penelitian tentang tingkat religiusitas pada mahasiswa yang mengikuti organisasi. Harapannya penelitian ini mampu memberikan gambaran yang tepat terkait tingkat religiusitas mahasiswa yang mengikuti organisasi. Selanjutnya dapat dijadikan data bagi peneliti selanjutnya untuk merencanakan penelitian yang lebih kompleks lagi.

\section{METODE}

Penelitian ini menggunakan metode penelitian deskriptif kuantitatif (Creswell, 2017; Yusuf, 2016; Azwar, 2014) yang dilakukan terhadap mahasiswa yang menjadi kader Ikatan Mahasiswa Muhammadiyah di Universitas Muhammadiyah Prof. DR. HAMKA, yang berjumlah 311 mahasiswa, yang diperoleh dengan menggunakan Probability Sampling, dengan teknik Cluster Sampling (Sugiyono, 2017). Data penelitian ini dikumpulkan menggunakan Islamic Religiosity Scale yang dikembangkan oleh Hermawan (2020). Skala ini mengacu pada dimensi religiusitas yang dikemukakan oleh Glock \& Stark, dimensi yang diukur dalam penelitian ini adalah religious belief (ideological dimension), religious practice (ritualistic dimension), religious feeling (experiential dimension), religious knowledge (intellectual dimension), and religious effects (consequential dimension) (Sari, Fajri, \& Syuriansyah, 2012; Basri, 2018).

Dalam penelitian ini, pengujian instrumen menggunakan uji validitas. Awal pengembangan skala terdiri dari 36 butir pernyataan. Mengacu pada hasil validitas, 35 item dinyatakan valid dan 1 item dinyatakan tidak valid yang kemudian didiskualifikasi. Adapun koefisien validitas item valid berupa corrected itemtotal correlation berada pada rentang mulai 0,249 sampai 0,597. Pengujian reliabilitas instrumen diperoleh koefisien Alpha Cronbach sebesar 0,827, artinya skala dinyatakan reliabel untuk digunakan mengukur religiusitas. Teknik analisis utama penelitian ini menggunakan teknik analisis deskriptif. Tahap pertama, melakukan uji statistik deskriptif, dilanjutkan mendeskripsikan partisipan pada kategorisasi yang mengacu pada model distribusi normal (statistik 
hipotetik). Adapun aplikasi yang religiusitas pada mahasiswa yang digunakan untuk pengolahan data yaitu mengikuti organisasi. Hasil uji statistik IBM SPSS Statistics 25.

deskriptif dinyatakan bahwa variabel religiusitas mempunyai nilai minimum

\section{HASIL DAN PEMBAHASAN}

\section{Hasil Penelitian}

Berdasarkan tujuan penelitian ini adalah untuk mendeskripsikan tingkat sebesar 35, nilai maksimum 175, mean 105, dan standar deviasi 23.3 (Hermawan, 2020). Hasil uji statistik deskriptif terdapat pada tabel berikut.

Tabel 1. Uji Statistik Deskriptif Mean Hipotetik

\begin{tabular}{|c|c|c|c|c|}
\hline \multirow{2}{*}{ Variabel } & \multicolumn{4}{|c|}{ Hipotetik } \\
\hline & Min & Maks & Mean & SD \\
\hline Religiusitas & 35 & 175 & 105 & 23.3 \\
\hline
\end{tabular}

Hasil uji statistik deskriptif pada tabel di atas mengacu pada tulisan (Azwar, 1993). Bahwa penggunaan statistik hipotetik menggunakan alat ukur sebagai acuan. Bahan penyusunan titik kategori, menggunakan rerata dan deviasi standar yang didapatkan dari alat ukur (Widhiarso, 2014). Selanjutnya yaitu melakukan uji asumsi klasik yaitu uji normalitas. Uji normalitas ini dilakukan dengan

\begin{tabular}{cl}
\hline $\mathrm{N}$ & One Sample Kolmogorov-Smirnov \\
& Test \\
\hline \multirow{2}{*}{ Religiusitas } & Exact Sig. (2-tailed) \\
& .080 \\
\hline
\end{tabular}

sehingga dapat dikatakan bahwa data

Berdasarkan hasil uji normalitas dengan menggunakan pendekatan exact (Cyrus R. Mehta and Nitin R. Pate, 2019) yang ditunjukkan pada tabel di atas, dapat dilihat bahwa data memiliki signifikansi sebesar 0.080 yaitu lebih besar dari 0.05
Smirnov Test dengan bantuan program statistik komputer IBM SPSS Statistics 25 for Windows. Kemudian peneliti menggunakan taraf signifikansi 5\%, jika nilai Kolmogorov-Smirnov memiliki tingkat signifikansi lebih besar dari 0,05 maka variabel penelitian dapat dikatakan berdistribusi normal. Hasil uji normalitas pada penelitian ini disajikan pada tabel berikut.

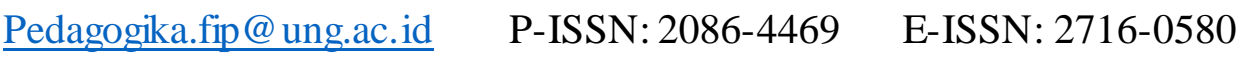


religiusitas pada mahasiswa yang Adapun datanya yaitu: Tingkat religiusitas mengikuti organisasi, dideskripsikan berdasarkan variabel beserta indikatornya yang dijadikan pernyataan dalam angket yang diberikan kepada seluruh mahasiswa yang mengikuti organisasi IMM tingkat Pimpinan Komisariat yang berada di mahasiswa yang mengikuti organisasi secara keseluruhan dengan jumlah responden 311 orang dari seluruh Pimpinan Komisariat di UHAMKA yang berjumlah 8 komisariat berdasarkan lima UHAMKA yang menjadi responden. kategorisasi adalah sebagai berikut.

Tabel 2. Distribusi Frekuensi dan Persentase Religiusitas

\begin{tabular}{ccc}
\hline \multicolumn{3}{c}{ Kategorisasi Data Hipote tik } \\
Kategori & Fre kuensi & Persen \\
Sangat Tinggi & 87 & $28 \%$ \\
Tinggi & 204 & $66 \%$ \\
Sedang & 20 & $6 \%$ \\
Rendah & 0 & $0 \%$ \\
Sangat Rendah & 0 & $0 \%$ \\
Total & 311 & $100 \%$
\end{tabular}

Berdasarkan data yang diperoleh dan peningkatan religiusitas yaitu kegiatan digambarkan pada tabel di atas perkaderan (Darul Arqam Dasar) sebagai menunjukkan bahwa religiusitas penguatan ideologi, kajian tauhid, mahasiswa yang mengikuti organisasi membaca buku-buku tauhid atau ideologi IMM dengan kategori sangat tinggi untuk memantapkan keyakinan terhadap sebanyak 87 orang dengan persentase sebesar 28\%. Kategori tinggi sebanyak 204 orang dengan persentase sebesar $66 \%$. Kategori sedang sebanyak 20 orang dengan persentase sebesar $6 \%$. Hasil ini artinya menunjukkan bahwa sebagian besar subjek penelitian yaitu memiliki tingkat religiusitas yang tergolong tinggi dan sangat tinggi.

Aktivitas mahasiswa yang ajaran agama, melaksanakan rutinitas salat wajib dan sunnah sesuai Himpunan Putusan Tarjih (HPT) Muhammadiyah, melaksanakan puasa wajib dan sunnah, membaca Al Quran, berdoa setelah salat, berdzikir, mengawali kegiatan rapat dengan membaca ayat suci Al Quran dan kultum untuk mengharapkan keberkahan dan menjadi pembiasaan, berdoa sebelum memulai aktivitas (Ayuningtyas, 2015).

mendukung hasil data di atas diantaranya, Aktivitas lainnya mengikuti kajiankegiatan-kegiatan yang dilakukan oleh kajian, mendengar kajian virtual dalam mahasiswa mendukung dalam upaya sosial media, pembahasan mengenai 
Himpunan Putusan $\quad$ Tarjih

Muhammadiyah, berdiskusi mengenai permasalahan agama, membaca buku-buku pengetahuan agama, penguatan karakter dan pembentukan perilaku yang baik melalui Pelatihan Administrasi dan Manajemen Organisasi (PAMOR), rapat koordinasi yang menjadikan evaluasi diri, saling membantu satu sama lain, serta melakukan aksi penggalangan dana kemanusiaan, selain daripada memberi, IMM juga membuka akses bagi orang lain untuk beramal. Dalam mencari jalan keluar dari setiap persoalan, IMM menggunakan kolektif kolegial, artinya mengedepankan musyawarah seperti yang dicontohkan Rasulullah SAW (Silmi, 2018). Hal ini menunjukkan bahwa IMM adalah organisasi yang membangun pikiran, perkataan, dan perbuatan berdasarkan nilai-nilai ketuhanan (Nur et al., 2017).

\section{Pembahasan}

Hasil dari penelitian ini adalah untuk menjawab tujuan penelitian, yaitu mendeskripsikan tingkat religiusitas pada mahasiswa yang mengikuti organisasi. Religiusitas seseorang dapat dipengaruhi berbagai faktor. Beberapa faktor yang dapat memengaruhi religiusitas diantaranya yaitu (1) faktor sosial, yaitu semua pengaruh sosial seperti: pendidikan dan pengajaran orang tua, tradisi ataupun tekanan sosial dalam kehidupan masyarakat (2) faktor alami, yaitu moral dan afektif. Hal ini terbentuk dari sebuah pengalaman seperti pengalaman konflik moral atau pengalaman emosional yang berkaitan dengan kondisi mental seseorang (3) faktor kebutuhan, yaitu seperti kebutuhan rasa aman, cinta, harga diri, kebutuhan yang timbul karena ancaman kematian. Dengan beragama, maka akan banyak hal positif yang didapatkan (4) Faktor intelektual, yaitu terbentuk akibat dari hubungan seseorang dengan proses pemikiran verbal, terutama dalam pembentukan keyakinan-keyakinan keagamaan (Thouless dalam Faujiah, Rahman, \& Yono, 2018).

Perolehan Data Masing-Masing Dimensi Religiusitas

\begin{tabular}{|c|c|c|c|c|c|c|}
\hline \multirow{2}{*}{ Dimensi } & \multicolumn{2}{|c|}{ Tinggi } & \multicolumn{2}{|c|}{ Sedang } & \multicolumn{2}{|c|}{ Rendah } \\
\hline & Jumlah & $\%$ & Jumlah & $\%$ & Jumlah & $\%$ \\
\hline Religious Belief & 283 & $91 \%$ & 28 & $9 \%$ & 0 & $0 \%$ \\
\hline $\begin{array}{l}\text { Religious } \\
\text { Practice }\end{array}$ & 218 & $70 \%$ & 93 & $30 \%$ & 0 & $0 \%$ \\
\hline $\begin{array}{l}\text { Religious } \\
\text { Feeling }\end{array}$ & 205 & $66 \%$ & 106 & $34 \%$ & 0 & $0 \%$ \\
\hline $\begin{array}{l}\text { Religious } \\
\text { Knowledge }\end{array}$ & 219 & $70 \%$ & 92 & $30 \%$ & 0 & $0 \%$ \\
\hline $\begin{array}{l}\text { Religious } \\
\text { Effects }\end{array}$ & 143 & $46 \%$ & 168 & $54 \%$ & 0 & $0 \%$ \\
\hline
\end{tabular}


Berdasarkan tabel data di atas, artinya mahasiswa memiliki dimensidimensi yang tinggi berdasarkan faktor yang dialami. Beberapa data serta kegiatan sebagai faktor pendukung yang memengaruhi peningkatan religiusitas mahasiswa yang mengikuti organisasi IMM UHAMKA terurai dalam paragraf berikut.

Dilihat pada dimensi keyakinan, mahasiswa yang mengikuti organisasi IMM UHAMKA memperoleh data 91\%, mahasiswa memiliki dimensi yang tinggi. Artinya individu yang memiliki aspek keyakinan yang tinggi memiliki pengetahuan dan keyakinan terhadap agama Islam yang tinggi. Beberapa kegiatan yang mendukung diantaranya yaitu pemberian materi aqidah Islam pada saat kegiatan Darul Arqam Dasar (Silmi, 2018), kajian bertemakan ketauhidan, membaca buku-buku tauhid atau ideologi untuk memantapkan keyakinan terhadap ajaran agama. Pada dimensi praktik keagamaan, diperoleh data $70 \%$, mahasiswa memiliki dimensi ritualitas yang tinggi. Hal ini sebagai bukti taat dalam melaksanakan ritual ibadah dengan didukung beberapa kegiatan diantaranya melaksanakan salat wajib dan sunnah, melaksanakan puasa wajib dan sunnah senin dan kamis (Islamiyah, 2019), membaca Al Quran, berdoa setelah salat, berdzikir, berqurban, dan lain-lain.

Pada dimensi penghayatan, diperoleh data $66 \%$, mahasiswa memiliki penghayatan terhadap agama yang tinggi, hal ini dibuktikan dengan beberapa kegiatan diantaranya ketika kegiatan rapat diawali dengan membaca ayat suci Al Quran dan kultum dengan mengharapkan keberkahan dan rapat berjalan dengan lancar (Ayuningtyas, 2015), berdoa sebelum memulai aktivitas. Pada dimensi pengetahuan agama diperoleh data sebesar $70 \%$, mahasiswa memiliki pengetahuan agama yang tinggi. Beberapa kegiatan yang mendukung dalam peningkatan pengetahuan agama diantaranya mengikuti kajian-kajian, mendengar kajian virtual dalam sosial media, pembahasan mengenai Himpunan Putusan Tarjih Muhammadiyah, berdiskusi mengenai permasalahan agama, membaca buku-buku pengetahuan agama, dan lain-lain.

Pada dimensi konsekuensi, diperoleh data sebesar 54\%, mahasiswa memiliki pengamalan dengan kategori sedang, $46 \%$ mahasiswa memiliki perilaku yang baik dan mengamalkan ajaran agama Islam dengan baik. Beberapa kegiatan yang mendukung dalam peningkatan dimensi konsekuensi diantaranya penguatan dan pembentukan karakter islami atau perilaku yang baik melalui kegiatan Pekan Ta'aruf, $\underline{\text { Pedagogika.fip@ ung.ac.id P-ISSN:2086-4469 E-ISSN: 2716-0580 }}$ 
Darul Arqam Dasar (Nugroho \& Rosita, 2019), dan Pelatihan Administrasi dan Manajemen Organisasi (Pamor). Selain daripada itu rapat koordinasi yang menjadikan evaluasi diri, melakukan bakti sosial di lingkungan masyarakat, memberikan pengajaran kepada anak-anak di lokasi binaan IMM, melakukan aksi menggalang dana kemanusiaan, yang tidak hanya memberi, tetapi juga membuka akses bagi orang lain untuk beramal. Hal di atas menjadi pendukung dalam peningkatan dimensi konsekuensi.

Hasil riset ini sama halnya dengan penelitian yang pernah dilakukan (Nurhanjani \& Wahyudi, 2019) terkait religiusitas mahasiswa PTN dan PTS di Bandung. Studi Nurhanjani \& Wahyudi (2019) terhadap religiusitas mahasiswa di Bandung menunjukkan memiliki keyakinan, praktik agama, pengetahuan agama, dan pengamalan ajaran agama yang tinggi. Mahasiswa memiliki keyakinan yang ditanamkan sejak lahir, melaksanakan praktik ibadah seperti salat wajib dan salat sunnah, kemudian puasa wajib dan sunnah, juga ibadah sunnah lainnya seperti membaca Al Quran, berdzikir, dan berdoa. Sama halnya di atas, temuan Marliani (2016) yang menyatakan bahwa pada hasil analisis deskriptif tingkat religiusitas mahasiswa memiliki tingkat religiusitas yang tinggi, hal ini dikarenakan mahasiswa yang memiliki tingkat praktik ibadah, mahasiswa berdisiplin ketika melaksanakan ritual ibadah, memiliki tingkat pengetahuan yang tinggi tentang agama, serta keyakinan yang tinggi.

Hal ini dipertegas dengan temuan (Raudatussalamah et al., 2017) Dalam penelitian Raudatussalamah et al., (2017) menyebutkan pada gambaran tingkat religiusitas mahasiswa, bahwa terdapat hasil mahasiswa memiliki religiusitas yang sangat tinggi. Hal ini dipengaruhi oleh aktivitas keagamaan aktual sehari-hari, komitmen terhadap agama, dan pengalaman spiritual yang diperoleh. Pengamalan rukun Iman, terdiri dari Iman kepada Allah, Iman kepada Malaikat, Iman kepada Kitab-Kitab Allah, Iman kepada Nabi dan Rasul, Iman kepada Hari Akhir, dan Iman kepada Qada dan Qadar. Kemudian pengamalan rukun Islam meliputi, mengucapkan dua kalimat syahadat, mendirikan salat, menjalankan puasa Ramadan, mengamalkan zakat, dan menunaikan ibadah haji bagi yang mampu. Selain daripada itu juga melakukan amalan-amalan lainnya yang harus dilakukan sebagai pemeluk agama. Komitmen dalam menjalankan ajaran serta nilai-nilai yang terkandung dalam agama, dan peduli terhadap aktivitas agama menjadikan mahasiswa lebih mampu akan 
makna tentang dirinya, bahkan hidup lebih berarti baik bagi dirinya maupun orang lain.

Berdasarkan hasil data dan studi literasi di atas, maka religiusitas perlu dipertahankan dengan terus melakukan penanaman nilai agama. Religiusitas sebagai keberagamaan tidak sebatas praktik ritual ibadah semata, melainkan ketika melakukan aktivitas lain yang terdapat dorongan kekuatan supranatural (Ancok \& Suroso dalam Juniarly \& Dahtiarani, 2020). Seperti yang sudah dijelaskan di atas yang menjelaskan bahwa religiusitas terdiri dari lima dimensi yaitu religious belief (ideological dimension), religious practice (ritualistic dimension), religious feeling (experiential dimension), religious knowledge (intellectual dimension), and religious effects (consequential dimension) (Glock dan Stark dalam Ancok dan Suroso, 2019). Ini membuktikan bahwa religiusitas tidak hanya ditunjukkan dengan salah satu dimensi saja, melainkan dari seluruh dimensi.

Individu yang religius akan terus mencoba untuk patuh terhadap ajaran agamanya, selalu berusaha mempelajari pengetahuan agama, menjalankan aktivitas ritual agama, meyakini doktrin-doktrin agama, serta merasakan berbagai pengalaman beragama. Setiap orang yang

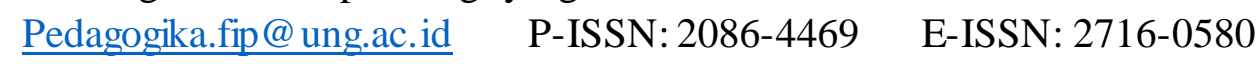

memiliki perilaku dan kehidupannya dipenuhi dengan aktivitas dimensi religiusitas maka dapat dikatakan religius. (Nashori dalam Ghufron \& Suminta 2012).

Berdasarkan hal tersebut, Glock dan Stark mengatakan bahwa pola perilaku dalam keseharian yang terbentuk dalam diri individu didasarkan pada internalisasi nilai-nilai agama (Ismail, 2009). Seseorang yang religius akan berusaha mengawasi perilakunya sehingga dapat menjauhkan dirinya dari perilaku yang tidak bermoral (Basri dalam Nusron, Widodo, \& Budiarto, 2019). Maka organisasi IMM sebagai mediator perlu mengemban tugas dalam menginternalisasi nilai-nilai ajaran agama Islam sebagai upaya mempertahankan religiusitas yang baik.

\section{SIMPULAN}

Berdasarkan hasil dan pembahasan, didapatkan simpulan bahwa tingkat religiusitas mahasiswa yang mengikuti organisasi IMM UHAMKA ini berada pada kategori tinggi dengan persentase $66 \%$ dan sangat tinggi $28 \%$. Hal ini dilihat dari kebiasaan mahasiswa yang melakukan kegiatan seperti memahami ketauhidan atau materi aqidah Islam melalui Darul Arqam Dasar dan kajian-kajian keislaman, memahami ideologi muhammadiyah, melakukan ibadah mahdhah dan ghairu mahdhah, menambah pengetahuan agama 
melalui berbagai sumber bacaan, berperilaku baik, dan menjadikan masjid sebagai basis interaksi sosial. Hal ini perlu menjadi perhatian semua pihak terkhusus bagi kader IMM, agar tidak masuk menjadi kategori sedang atau rendah. Penelitian ini diharapkan dapat menjadi bahan yang membangun dan penguat bagi setiap mahasiswa yang tergabung dalam organisasi IMM, khususnya di UHAMKA. Maka perlu ada upaya untuk mempertahankan religiusitas dari berbagai dimensi demi terciptanya nilai perkaderan dan pergerakan IMM yang baik.

\section{REFERENSI}

Alwi, S. (2014). Perkembangan Religiusitas Remaja (1st ed.). Yogyakarta: Kaukaba Dipantara.

Amirullah. (2016). IMM Untuk Kemanusiaan; Dari Nalar ke Aksi. Jakarta: CV Mediatama Indonesia. 1413.

Ancok dan Suroso. (2019). Psikologi Islami (VIII). Yogyakarta: Pustaka Pelajar.

Ayuningtyas, M. (2015). Nilai-Nilai Pendidikan Islam dalam Organisasi Ikatan Mahasiswa Muhammadiyah Komisariat Muhammad Abduh Fakultas Agama Islam Universitas Muhammadiyah Surakarta Periode 2014. Naskah Publikasi, 151, 10-17.

Azwar, S. (1993). Kelompok Subjek Ini Memiliki Harga Diri Yang Rendah"; Kok, Tahu...? Buletin Psikologi, 1(2), 13-17.

https://doi.org/10.22146/bpsi.13160

Pedagogika.fip@ung.ac.id
Azwar, S. (2014). Metodologi Penelitian (XV). Yogyakarta: Pustaka Pelajar.

Basri, A. S. H. (2018). Prokrastinasi Akademik Mahasiswa Ditinjau Dari Religiusitas. Hisbah: Jurnal Bimbingan Konseling Dan Dakwah Islam, 14(2). https://doi.org/10.14421/hisbah.2017. $142-05$

Chamadi, M. R., \& Sumantri, R. A. (2019). Tipologi Gerakan Mahasiswa Melalui Organisasi Mahasiswa Islam Di Purwokerto. Titian: Jurnal Ilmu Humaniora, 03(02), 241-259.

Cyrus R. Mehta and Nitin R. Pate. (2019). Correlation between carotid intimamedia thickness and serum TNFalpha levels in female with rheumatoid arthritis of different ethnicities: A single-centre experience in Malaysia. Makara Journal of Health Research, 176180.

https://doi.org/10.7454/msk.v23i3.11 45

Darokah, M., \& Safaria, T. (2005). Perbedaan Tingkat Religiusitas, Kecerdasan Emosi, dan Keluarga Harmonis pada Kelompok Pengguna Napza dengan kelompok Non Pengguna. Indonesian Psychological, 2(2), 89-101. Retrieved from http//journal.uad.ac.id/index.php/HU MANITAS/article/view/318/210

Faujiah, R. A., Rahman, I. K., \& Yono, Y. (2018). Prokrastinasi Akademik Ditinjau dari Religiusitas Siswa di SMA Negeri 10 Bogor. Ta'dib: Jurnal Pendidikan Islam, 7(2), 43-52. https://doi.org/10.29313/tjpi.v7i2.395 2

Ghufron, M. N. \& S. R. R. (2012). TeoriTeori Psikologi (III; R. Kusumaningratri, ed.). Yogyakarta: AR-RUZZ MEDIA.

Hadziq, A. (2019). Nasionalisme P-ISSN: 2086-4469 E-ISSN: 2716-0580 
Organisasi Mahasiswa Islam dalam Menangkal Radikalisme di Institut Agama Islam Negeri (IAIN) Surakarta. Jurnal Pendidikan Agama Islam Al-Thariqah, 4(1), 50-59. https://doi.org/10.25299/althariqah.2019.vol4(1).2791

Hermawan, D. (2020a). Forus: Program Analisis Kategorisasi Skor Skala Psikologi. Jakarta: UHAMKA.

Hermawan, D. (2020b). Hubungan Antara Religiusitas dengan Kesepian pada Mahasiswa. Skripti. Tidak Diterbitkan. Jakarta: UHAMKA.

Hulukati, W., \& Djibran, M. R. (2018). Analisis Tugas Perkembangan Mahasiswa Fakultas Ilmu Pendidikan Universitas Negeri Gorontalo. Bikotetik (Bimbingan Dan Konseling: Teori Dan Praktik), 2(1), 73. https://doi.org/10.26740/bikotetik.v2n 1.p73-80

Huriati, \& Hidayah, N. (2016). Krisis Identitas Diri pada Remaja. Sulesana, 10(1), 49-62. Retrieved from http://journal.uinalauddin.ac.id/index.php/sls/article/vi ew/1851

Iflah, I., \& Listyasari, W. D. (2013). Gambaran Penyesuaian Diri Mahasiswa Baru. JPPP - Jurnal Penelitian Dan Pengukuran Psikologi, 2(1), 33-36. https://doi.org/10.21009/jppp.021.05

Islamiyah, H. (2019). Bimbingan Konseling Qur'ani dalam Pembentukan Karakter Religius pada Kader Ikatan Mahasiswa Muhammadiyah (IMM) UIN Sunan Ampel Surabaya. Skripsi, 8(5), 55.

Ismail, W. (2009). Analisis Komparatif Perbedaan Tingkat Religiusitas Siswa Di Lembaga Pendidikan Pesantren, Man, Dan Smun. Lentera Pendidikan: Jurnal Ilmu Tarbiyah Dan Keguruan, 12(1), 87-102. https://doi.org/10.24252/lp.2009v12n $1 \mathrm{a} 7$

Juniarly, A., \& Dahtiarani, D. (2020). Peran Religiusitas terhadap Konformitas pada Mahasiswi Berhijab. Jurnal RAP (Riset Aktual Psikologi Universitas Negeri Padang), 10(2), 224. https://doi.org/10.24036/rapun.v10i2. 106631

Koenig, H. (2018). Religion and Mental Health: Research and Clinical Applications. In Religion and Mental Health: Research and Clinical Applications.

Kurniawan, F., \& Dwiyanti, R. (2013). Hubungan religiusitas dengan kontrol diri pada anggota intelkam polres cilacap. Jurnal Psikologi, 54-60.

Lestari, M. D. (2017). Perkaderan Intelektual Pimpinan Cabang Ikatan Mahasiswa Muhammadiyah Kabupaten Sukoharjo. 15(1).

Listiari, E. (2011). Hubungan Antara Tingkat Religiusitas dan Pengendalian Diri pada Remaja Tingkat SMA. Jurnal Psikologi, Vol. 7, pp. 56-66. Retrieved from https://ejournal.up45.ac.id/index.php/ psikologi/article/view/129/125

Marliani, R. (2013). Hubungan Antara Religiusitas Dengan Orientasi Masa Depan Bidang Pekerjaan Pada Mahasiswa Tingkat Akhir. Jurnal Psikologi UIN Sultan Syarif Kasim Riau, 9(Desember), 130-137.

Marliani, R. (2016). Hubungan Antara Religiusitas dengan Prestasi Belajar pada Mahasiswa Fakultas Syariah dan Hukum UIN Sunan Gunung Djati Bandung Angkatan 2012. Jurnal Psikologi Integratif, Vol. 4, pp. 136147.

Muchtar, D. Y. (2019). Peran religiusitas dalam pembentukan konsep diri 
remaja. TAZKIYA: Journal of Psychology, 3(2), 179-191. https://doi.org/10.15408/tazkiya.v20i 2.9165

Nuandri, V. T., \& Widayat, I. W. (2014). Hubungan Antara Sikap terhadap Religiusitas dengan Sikap terhadap Kecenderungan Perilaku Seks Pranikah pada Remaja Akhir yang Sedang Berpacaran di Universitas Airlangga Surabaya. Jurnal Psikologi Kepribadian Dan Sosial, 3(2), 60-69.

Nugroho, A., \& Rosita. (2019). Peranan Ikatan Mahasiswa Muhammadiyah dalam Membentuk Karakter Islami Mahasiswa di Universitas Muhammadiyah Purwokerto 1,2). Prociding Seminar Nasional Prodi PAI UMP Tahun 2019, 203-216.

Nur, F., \& Ramli, R. (2017). Pengaruh Kepengurusan Ikatan Mahasiswa Muhammadiyah Terhadap Pengembangan Soft Skill Mahasiswa. Istiqra', IV(2), 213-228.

Nurhanjani, N., \& Wahyudi, H. (2019). Studi Deskriptif Mengenai Dimensi Religiusitas pada Mahasiswa yang Melakukan Kohabitasi di Tempat Kost X Bandung. Prosiding Psikologi, 352-358. Retrieved from http://repository.unisba.ac.id/handle/1 23456789/21770

Nusron, L. Amalia, Widodo, S., \& Budiarto, D. setyo. (2019). Apakah Good University Governance Berhubungan Dengan Religiusitas Mahasiswa? Jurnal Ilmiah Ekonomi Dan Bisnis, 16(2), 110-121. https://doi.org/10.31849/jieb.v16i2.23 26

Oetomo, P. F., Yuwanto, L., \& Rahaju, S. (2019). Faktor Penentu Penyesuaian Diri pada Mahasiswa Baru Emerging Adulthood Tahun Pertama dan Tahun Kedua. Jurnal Ilmiah Psikologi MIND SET, 8(02), 67-77. https://doi.org/10.35814/mindset.v8i0 2.325

Putri, F. (2012). Perbedaan Tingkat Religiusitas dan Sikap Terhadap Seks Pranikah Antara Pelajar yang Bersekolah di SMA Umum dan SMA Berbasis Agama. CALYPTRA: Jurnal Ilmiah Mahasiswa Universitas ..., 1(1), 1-9. Retrieved from https://journal.ubaya.ac.id/index.php/j imus/article/view/45

Raudatussalamah;, \& Susanti, R. (2017). The Role of Religiousity: Keikutsertaan dalam Pembinaan Keislaman Mahasiswa dan Implikasinya Terhadap Kesejahteraan Psikologis Mahasiswa Tahun Pertama. Jurnal Psikologi Islam, 4(2), 181-190. Retrieved from http:/jpi.apihimpsi.org/index.php/jpi/article/down load/48/20/

Rosiana, D. (2011). Penyesuaian Akademis Mahasiswa Tingkat Pertama. Prosiding SNaPP: Sosial, Ekonomi Dan Humaniora, 2(1), 491496. Retrieved from http $/ /$ proceeding.unisba.ac.id/index.p $\mathrm{hp} / \mathrm{sosial} /$ article/view/309

Sari, Y., Fajri, A., \& Syuriansyah, T. (2012). Religiusitas Pada Hijabers Community Bandung. Prosiding Seminar Nasional Penelitian Dan PKM: Sosial, Ekonomi, Dan Humaniora, 3(1), 311-318.

Sasmitho, A. M. (2013). Hubungan Antara Religiusitas Dengan Konsep Diri Mahasiswa Program Studi Bimbingan dan Konseling Universitas Negeri Yogyakarta Angkatan 2010. Skripsi, 66(1997), 37-39.

Sholeh, A. (2017). IMM Autentik Melacak Autentisitas dan Substansi Gerakan Ikatan Mahasiswa Muhammadiyah (1st ed.). Surabaya: Pustaka Saga.

Silmi, L. (2018). Internalisasi Ajaran Islam Pedagogika.fip@ung.ac.id

P-ISSN: 2086-4469 E-ISSN: 2716-0580 
pada Kegiatan Ikatan Mahasiswa Muhammadiyah Komisariat Pondok Internasional K.H. Mas Mansur Periode 2017. Publikasi Ilmiah, 1(1), 1-8. Retrieved from http://dx.doi.org/10.1016/j.cirp.2016. 06.001\%0Ahttp://dx.doi.org/10.1016/ j.powtec.2016.12.055\%0Ahttps://doi. org/10.1016/j.ijfatigue.2019.02.006\% 0Ahttps://doi.org/10.1016/j.matlet.20 19.04.024\%0Ahttps://doi.org/10.1016 /j.matlet.2019.127252\%0Ahttp//dx.d oi.o

Sugiyono. (2017). Metode Penelitian Pendidikan Pendekatan Kuantitatif, Kualitatif, dan $R \& D$ (25th ed.).
Bandung: Alfabeta.

Sutanti, K. et al. (2011). Sistem Perkaderan Ikatan. Retrieved from http:/library1.nida.ac.th/termpaper6/s d/2554/19755.pdf

Widhiarso, W. (2014). Pengategorian data dengan menggunakan statistik hipotetik dan statistik empirik. Fakultas Psikologi. Universitas Gajah Mada., 1-3. Retrieved from http $/ /$ widhiarso.staff.ugm.ac.id/wp/w p-content/uploads/WidhiarsoPengategorian-Data-denganMenggunakan-Statistik-Hipotetikdan-Statistik-Empirik.pdf 